The Geographical Journal of Nepal

Vol. 15: 83-102, 2022

DOI: https://doi.org/10.3126/gjn.v15i01.42888

Central Department of Geography,

Tribhuvan University, Kathmandu, Nepal

\title{
Hydrochemical characterization of lentic and lotic environments of Ramaroshan area, Sudurpaschim Province, Nepal
}

\author{
Alina Dangol ${ }^{1}$, Ramesh Raj Pant ${ }^{1 *}$, Tarka Bahadur Chalaune ${ }^{1}$, Jiban \\ Sharma $^{1}$, Bina Thapa ${ }^{1}$, Lal B Thapa ${ }^{2}$, Kiran Bishwakarma ${ }^{3,4}$ \\ ${ }^{1}$ Central Department of Environmental Science, Tribhuvan University, Kathmandu, Nepal \\ ${ }^{2}$ Central Department of Botany, Tribhuvan University, Kathmandu, Nepal \\ ${ }^{3}$ State Key Laboratory of Tibetan Plateau Earth System, Resources and Environment, Institute \\ of Tibetan Plateau Research, Chinese Academy of Sciences, Beijing 100101, China \\ ${ }^{4}$ University of Chinese Academy of Sciences, Beijing 100049, China \\ *Corresponding author: rpant@cdes.edu.np
}

Received: 17 November, 2021; Accepted: 16 December, 2021; Published: March, 2022

\begin{abstract}
Ramaroshan of Sudurpaschim Province is rich in biodiversity, and ecologically distinct but scientifically unexplored rural and remote area of Nepal. There is a holy perennial Kailash River as a lotic and aesthetically well-known Ramarosan Lake Cluster (Batula Lake) as a lentic environment located in the region. This study has analyzed and then characterized the water quality status of both the lentic and lotic environments. The physicochemical parameters such as temperature, $\mathrm{pH}$, electrical conductivity (EC), total dissolved solids (TDS), and major ions were analyzed for the hydrochemical characterization. The results revealed that the dominancy orders of cations and anions of the study area were found to be $\mathrm{Ca}^{2+}>\mathrm{Na}^{+}>\mathrm{Mg}^{2+}>\mathrm{K}^{+}>\mathrm{NH}_{4}^{+}$and $\mathrm{HCO}_{3}^{-}>\mathrm{Cl}^{-}>\mathrm{SO}_{4}^{2-}>\mathrm{PO}_{4}^{3-}>\mathrm{NO}_{3}^{-}$, respectively. The concentrations of most of the parameters were relatively higher in the Kailash River than the Batula Lake except for the $\mathrm{SO}_{4}^{2-}, \mathrm{PO}_{4}^{3-}$ and $\mathrm{NH}_{4}^{+}$. The water facies displayed the $\mathrm{Ca}-\mathrm{HCO}_{3}$ type indicating the calcium carbonate type of lithology in the area. Additionally, the carbonate weathering is also higher than the silicates and evaporates. Similarly, the source controlling mechanisms indicated that the hydrochemistry of the Ramaroshan area is determined by both geogenic weathering and precipitation. Water quality assessment for irrigation parameters confirmed its suitability for irrigational purposes. The finding of this study could be the baseline dataset for assessing the future status and management of water resources of the Ramaroshan area.
\end{abstract}


Keywords: Hydrochemistry, weathering, irrigation parameters, Ramaroshan area

\section{Introduction}

Water resources are the backbone for economic development and ecological integrity (Wu et al., 2018). From the ecological perspective, the ecosystem services from freshwater such as drinking water, regulating climate patterns, hydropower generation, ecotourism, soil formation, and groundwater recharge have been a foundation for human civilization. However, there is always a great challenge in securing water to satisfy the requirements of humans and ecosystems with rampant development, global climate change, and rapid urbanization (Amangabara \& Ejenma, 2012). Both the natural processes and the anthropic activities alter the chemical compositions of the freshwater resources. Even the high mountain water resources, which are supposed to be pristine, are found to be vulnerable and threatened by anthropic activities like longrange transport of pollutants (Battarbee et al., 2002, Grabherr et al., 2006; Rupakheti et al., 2017, Gurung et al., 2018), climate change (Adrian et al., 2009), tourism, religious activities, and pollution (Chandan et al. 2008; Neupane et al., 2010).

The hydrochemical characterization is widely applied to evaluate the water bodies' physical, chemical, and biological status (Steingruber \& Colombo, 2006). The chemical composition provides baseline information about weathering as ecological changes (Barnett et al., 2005; Zhu et al., 2012; Hagedorn \& Whittier, 2015). So, the study on the hydrochemical characteristics of water bodies like rivers and lakes has been paid much more attention (Tripathee et al., 2014; Xiao et al., 2015; Nazri et al., 2016; Yang et al., 2017).

In Nepal, hydrochemical studies have been performed at different spatial and temporal levels such as Rara, Begnas, Rupa, Nagdaha, and Betkot lakes, and Gandaki River Basin, and so on (Khadka \& Ramanathan, 2013; Pant, 2013; Gurung et al., 2018; Pant et al., 2018; Pant et al., 2019a; 2019b). However, the rural and remote areas of Nepal for instance high-land areas of Sudurpaschim Province are yet to be explored. Ramaroshan area of the province is one of them. The area is renowned for its 12 lakes and 18 Patans (lust grassland) in the junction of 3 districts viz. Accham, Bajura and Kalikot. It lies 42 $\mathrm{km}$ away from Mangalsen the district headquarters of Achham district. The climate of the area is sub-tropical, mild temperate, and cool-temperate. Geologically, the study area belongs to the Kalikot and Salyanigad formations. Kalikot formation has Budhi Ganga gneiss group and Ghattegad carbonates group (limestone, calcareous schist, and quartz biotite schists), whereas Salyanigad formation consists of gneisses augen, aplite granite, gneisses, and biotite gneisses (Dahal, 2017). The main objective of this study is to reveal the hydrochemistry of the lentic and lotic water bodies of the Ramaroshan Area. 


\section{Methodology}

\section{The study area}

The Kailash River and Lake Cluster of Ramaroshan area (Batula Lake) was the study area (Fig. 1) for hydrochemical characterization. Batula Lake (Geographic Location: $29^{\circ} 13^{\prime} \mathrm{N} \& 81^{\circ} 28^{\prime} \mathrm{E}$ ) is one of the lakes of the Ramaroshan Lake Complex Area (RLCA) located at an altitude of $2406 \mathrm{~m}$ asl, with a basin area of 249.6 ha and core area of 3.2 ha. The lake has an average depth of $5 \mathrm{~m}$ with a maximum depth of $15 \mathrm{~m}$ (Chalaune et al., 2020). The Kailash River is one of the main rivers that flow down the hills of the Ramaroshan Area. The water discharge from Batula Lake is confluence into the Kailash River. The catchment area of Kailash River is home to 112 flowering plants and 12 species of cryptogames, eight species of wetland-dependent birds including migratory species (Poudel \& Adhikari, 2020).

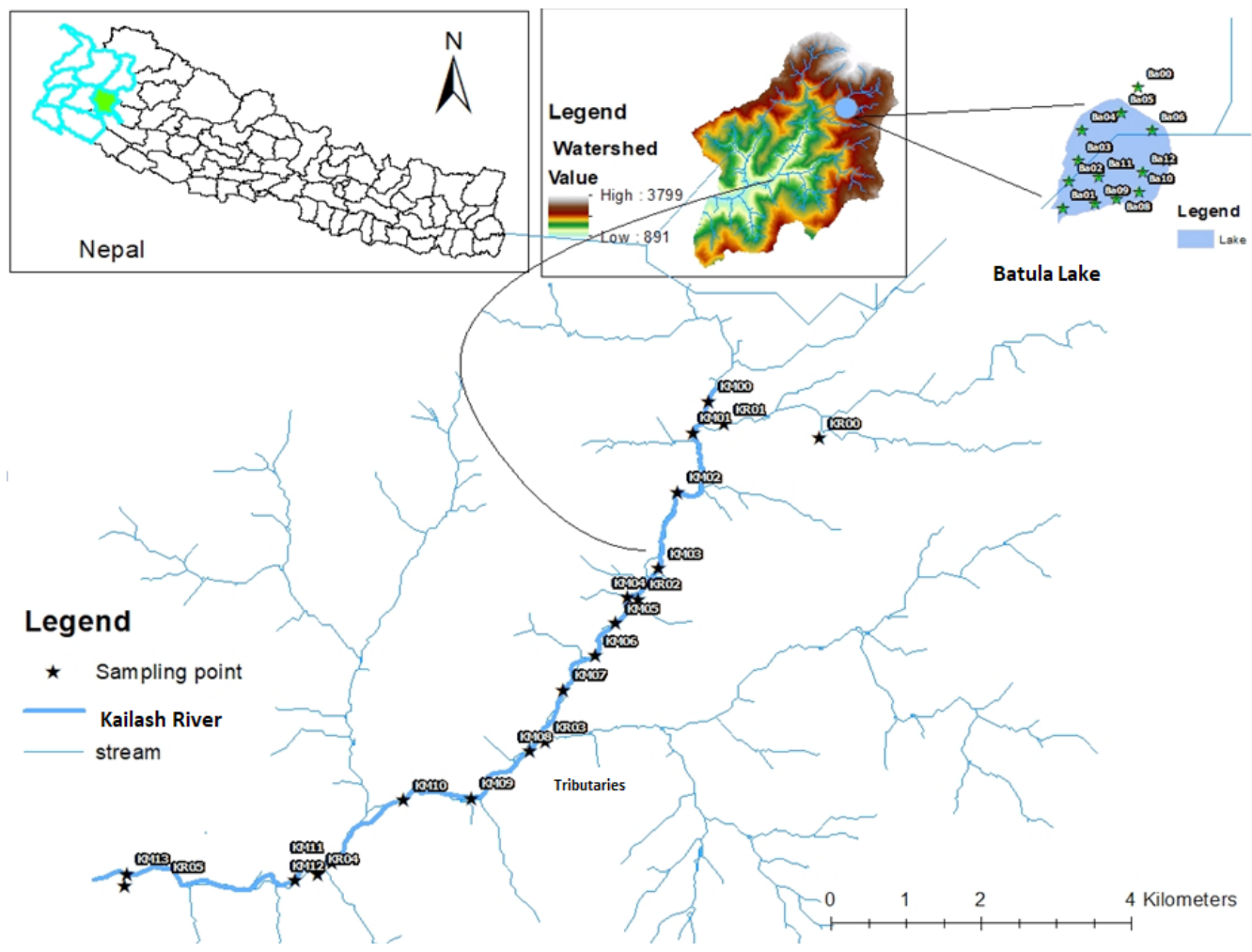

Figure 1: Study map showing the sampling points of Batula Lake and Kailash River, Ramaroshan area, Sudurpashchim Province, Nepal 


\section{Sampling}

Surface water samples were collected in the month of January 2020. The sampling was conducted on the basis of land use/land cover change, and other environmental characteristics. Altogether 35 samples of water were collected of which 13 were collected from Batula Lake and 14 from the main Kailash River, and 8 from its tributaries. The samples were collected from the depth of $15 \mathrm{~cm}$ in $1 \mathrm{~L}$ and $250 \mathrm{~mL}$ HDPE bottles. The samples for cations were preserved by adding conc. $\mathrm{HNO}_{3}$ for maintaining $\mathrm{pH}$ $<2$. The $\mathrm{pH}$, transparency, temperature, EC, and TDS were determined in-situ using HANNA multipurpose meter. Similarly, the concentrations of calcium $\left(\mathrm{Ca}^{2+}\right)$ and magnesium $\left(\mathrm{Mg}^{2+}\right)$ were determined in-situ by the complex-metric titration method. Sodium $\left(\mathrm{Na}^{+}\right)$and potassium $\left(\mathrm{K}^{+}\right)$were analyzed through the flame photometer in the lab. The concentration of bicarbonate $\left(\mathrm{HCO}_{3}^{-}\right)$, carbonate $\left(\mathrm{CO}_{3}{ }^{2-}\right)$, and chloride $\left(\mathrm{Cl}^{-}\right)$ were analyzed in-situ through titration whereas, sulfate $\left(\mathrm{SO}_{4}^{2-}\right)$, nitrate $\left(\mathrm{NO}_{3}^{-}\right)$, phosphate $\left(\mathrm{PO}_{4}^{3-}\right)$, and ammonia $\left(\mathrm{NH}_{4}^{+}\right)$by the spectrophotometer in the laboratory. Calibration of equipment with standards and use of blank for reagent quality were adopted for quality control. For the overall analysis, APHA (2005) was referred for analysis in Central Department of Environmental Science, Institute of Science and Technology, Tribhuvan University, Nepal.

\section{Data analysis}

Descriptive statistics, as well as graphical analysis, were performed to evaluate and interpret the obtained dataset in this study. Piper plot (Piper, 1944), Gibbs diagram (Gibbs, 1970), and mixing diagrams were used for understanding hydrochemical characteristics. Principal component analysis (PCA) and hierarchical cluster analysis (CA) were used in order to identify the source of major ions and correlate between them. Descriptive statistics were done using SPSS version 26.0 and MS Excel 2016. Water suitability for irrigation was determined by using the following parameters:

Sodium absorption ratio $(\mathrm{SAR})=\frac{N a^{+}}{\sqrt{\left(C a^{2+}+M g^{2+}\right) / 2}}($ Richards, 1954)

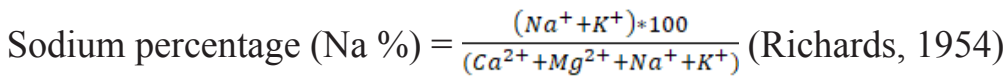

Kelly's ratio $(\mathrm{KR})=\frac{N a^{+}}{\left(C a^{2+}+M g^{2+}\right)}($ Kelly, 1940)

Permeability index (PI) $=\frac{\left(\mathrm{Na}^{+}+\sqrt{\mathrm{HCO}_{3}^{-}}\right) * 100}{\mathrm{Ca}^{2+}+\mathrm{Mg}^{2+}+\mathrm{Na}^{+}}$(Doneen, 1964)

Magnesium Hazard $(\mathrm{MH})=\frac{M g^{2+}{ }_{* 100}}{\left(C a^{2+}+M g^{2+}\right)}($ Rengasamy \& Marchuk, 2011)

Wilcox diagram (Wilcox, 1958) 


\section{Results and discussion}

\section{General hydrochemistry}

Table 1 summarized the results obtained from the analysis of the water samples. The table contains average, standard deviation (SD), maximum (max.), and minimum (min.) concentrations of the 14 water parameters. Based on the mean $\mathrm{pH}$ value in Kailash River, the water is slightly alkaline as the maximum value recorded was 8.26. This might be due to the high concentration of the bicarbonate-dominated under-lying lithology (Begum et al., 2009).

Table 1: Summary of the hydrochemical parameters of Batula Lake and Kailash River, Ramaroshan area, Sudurpashchim Province, Nepal

\begin{tabular}{|c|c|c|c|c|c|c|c|c|c|}
\hline \multirow[t]{2}{*}{ Parameters } & \multicolumn{4}{|c|}{ Batula Lake } & \multicolumn{4}{|c|}{ Kailash River } & \multirow{2}{*}{$\begin{array}{l}\text { WHO } \\
\text { limits }\end{array}$} \\
\hline & Average & SD & Min & Max & Average & SD & Min & Max & \\
\hline Tem. & 8.26 & 3.51 & 3.30 & 15.30 & 11.17 & 0.95 & 8.70 & 12.40 & \\
\hline $\mathrm{pH}$ & 7.43 & 0.17 & 7.13 & 7.69 & 7.74 & 0.36 & 6.62 & 8.26 & $6-8.5$ \\
\hline $\mathrm{EC}$ & 67.85 & 31.76 & 20.00 & 106.00 & 126.00 & 73.26 & 45.00 & 322.00 & . \\
\hline TDS & 34.85 & 16.6 & 10.00 & 54.00 & 65.00 & 38.56 & 24.00 & 168.00 & 1000 \\
\hline $\mathrm{Ca}^{2+}$ & 10.28 & 4.67 & 2.40 & 16.00 & 20.22 & 14.97 & 8.00 & 66.40 & 100 \\
\hline $\mathrm{Mg}^{2+}$ & 3.27 & 1.46 & 0.98 & 5.86 & 5.10 & 2.10 & 1.46 & 10.25 & 50 \\
\hline $\mathrm{Na}^{+}$ & 5.50 & 0.25 & 5.10 & 6.10 & 5.76 & 0.18 & 5.40 & 6.10 & 200 \\
\hline $\mathrm{K}^{+}$ & 2.30 & 0.64 & 1.09 & 3.30 & 2.80 & 0.94 & 0.08 & 4.60 & 100 \\
\hline $\mathrm{NH}_{4}^{+}$ & 0.12 & 0.09 & 0.07 & 0.43 & 0.09 & 0.02 & 0.07 & 0.14 & 0.5 \\
\hline $\mathrm{HCO}_{3}^{-}$ & 39.23 & 14.92 & 15.00 & 60.00 & 54.45 & 33.79 & 20.00 & 140.00 & 600 \\
\hline $\mathrm{Cl}^{-}$ & 12.12 & 3.42 & 7.10 & 18.46 & 14.03 & 3.60 & 7.10 & 22.72 & 250 \\
\hline $\mathrm{NO}_{3}^{-}$ & 0.05 & 0.01 & 0.04 & 0.07 & 0.05 & 0.01 & 0.04 & 0.08 & 50 \\
\hline $\mathrm{SO}_{4}^{2-}$ & 1.96 & 3.29 & 0.29 & 12.67 & 1.62 & 0.52 & 0.99 & 3.62 & 250 \\
\hline $\mathrm{PO}_{4}^{4-}$ & 0.22 & 0.12 & 0.13 & 0.56 & 0.16 & 0.03 & 0.02 & 0.22 & 1 \\
\hline
\end{tabular}

The mean value of EC and TDS was found to be $126.00 \pm 73.26 \mu \mathrm{S} / \mathrm{cm}$ and $65.00 \pm 38.56$ $\mathrm{mg} / \mathrm{L}$, respectively in the Kailash River, whereas the mean value recorded in Batula Lake was $67.85 \pm 30.4 \mu \mathrm{S} / \mathrm{cm}$ and $34.85 \pm 16.6 \mathrm{mg} / \mathrm{L}$. These values were under the guideline provided by WHO limits. The higher concentration of TDS and EC in Kailash River than Batula Lake might be due to the high concentration of the ionic species and weathering of the chemicals with the movement of river water (Singh \& Hasnain, 1999; Das \& Kaur 2001). Previous studies have shown that the majority of Himalayan freshwater bodies have relatively very low TDS values $(<100 \mathrm{mg} / \mathrm{L})$ (Pant et al., 2018). In the present study, the lake and river being at high altitude have shown a similar trend except for some samples from the tributary of Kailash River. Similarly, the TDS and EC were found to be $94.75 \pm 3.29 \mathrm{mg} / \mathrm{L}$ and $189.93 \pm 5.3 \mu \mathrm{S} / \mathrm{cm}$, respectively in Rara Lake 
(Gurung et al., 2018) which is greater than the present study concentration of Batula Lake. The mean concentrations of major ions were greater in the Kailash River than the Batula Lake except for $\mathrm{SO}_{4}^{2-}, \mathrm{PO}_{4}^{3-}$ and $\mathrm{NH}_{4}^{+}$which is greater in Batula Lake. The reason behind having greater value for $\mathrm{PO}_{4}^{3-}$ and $\mathrm{NH}_{4}^{+}$may be organic matter, dead logs, and macrophytes in Batula Lake. In this study, $\mathrm{HCO}_{3}^{-}$was only the anion that primarily contributed to the total alkalinity. The mean concentration of $\mathrm{HCO}_{3}{ }^{-}$recorded was 39.23 $\pm 14.92 \mathrm{mg} / \mathrm{L}$ and $53.24 \pm 32.63 \mathrm{mg} / \mathrm{L}$ in Batula and Kailash River, respectively. A high concentration of $\mathrm{HCO}_{3}^{-}$in the Kailash might be contributed to weathering reactions (Chakrapani et al., 2009). The maximum concentration of chloride was recorded from the water sample near the settlement area of the Kailash River. The greywater from the settlement area is directly mixed in the Kailash River which might be the reason for higher chlorides. The mean concentration of $\mathrm{Cl}^{-}$was $12.12 \pm 3.43 \mathrm{mg} / \mathrm{L}$ in Batula Lake which is found to be lower than previous studies of lakes like Begnas, Rupa, Khaste Lake (Pant et al., 2019a) but higher than Jhilmila (Pal et al., 2021) and Betkot Lake (Pant et al., 2019b) from the western region of Nepal.

The mean concentrations of cations were in the order of $\mathrm{Ca}^{2+}>\mathrm{Na}^{+}>\mathrm{Mg}^{2+}>\mathrm{K}^{+}>\mathrm{NH}_{4}^{+}$ in both Kailash River and Batula Lake. A similar order was observed in the Tamor River (Ghimire et al., 2021), Bagmati River, and Jhilmila Lake but slightly different than Gandaki River (Pant et al., 2018). Meanwhile, the mean concentration of anions were in the order of $\mathrm{HCO}_{3}^{-}>\mathrm{Cl}^{-}>\mathrm{SO}_{4}^{2-}>\mathrm{PO}_{4}^{3-}>\mathrm{NO}_{3}^{-}$in the study area. The mean concentrations of major ions were under the guidelines of WHO that the water is also suitable for drinking purposes as people depend on these resources for drinking.

\section{Hydrochemical facies}

For the characterization and source identification of the major ions, Piper Plot (Piper, $1944)$ was used. The milliequivalent percentage (meq\%) of the major ions is plotted in a trilinear diagram (Figure 2) illustrating the water characteristics of the Batula Lake and Kailash River. On the cation plot, most of the samples from both the study area had $\mathrm{Ca}^{2+}$ as the dominant cation. Similarly, the anion plot showed that $\mathrm{HCO}_{3}^{-}$and $\mathrm{Cl}^{-}$were dominant anions in samples of both the Batula Lake and Kailash River. The Piper plot showed the dominance of alkaline earth metal over alkali metal such as $\mathrm{Ca}^{2+}+\mathrm{Mg}^{2+}>$ $\mathrm{Na}^{+}+\mathrm{K}^{+}$and anions such as $\mathrm{HCO}_{3}^{-}>\mathrm{SO}_{4}{ }^{2-}+\mathrm{Cl}^{-}$. The diamond plot can be classified into the six water facies i.e. 1) $\mathrm{Ca}-\mathrm{HCO}_{3}$ 2) $\mathrm{Na}-\mathrm{Cl}, 3$ ) Mixed $\mathrm{Ca}-\mathrm{Na}-\mathrm{HCO}_{3}$, 4) Mixed Ca$\mathrm{Mg}-\mathrm{Cl}, 5) \mathrm{Ca}-\mathrm{Cl}, 6) \mathrm{Na}-\mathrm{HCO}_{3}$ (Khadka \& Ramanatha, 2012). As per the classification, the water type was found to be $\mathrm{Ca}-\mathrm{HCO}_{3}$ type and $\mathrm{Ca}-\mathrm{Mg}-\mathrm{Cl}$ type in both ecosystems. About $95 \%$ of samples in Kailash River and $84 \%$ of samples from Batula Lake had the $\mathrm{Ca}-\mathrm{HCO}_{3}$ type whereas $5 \%$ and $16 \%$ of samples in Kailash River and Batula Lake were 
found to have $\mathrm{Ca}-\mathrm{Mg}-\mathrm{Cl}$ type of water, respectively. The dominance of $\mathrm{Ca}-\mathrm{HCO}_{3}$ water type and alkaline earth metal signifies the carbonate-dominated underlying lithology.

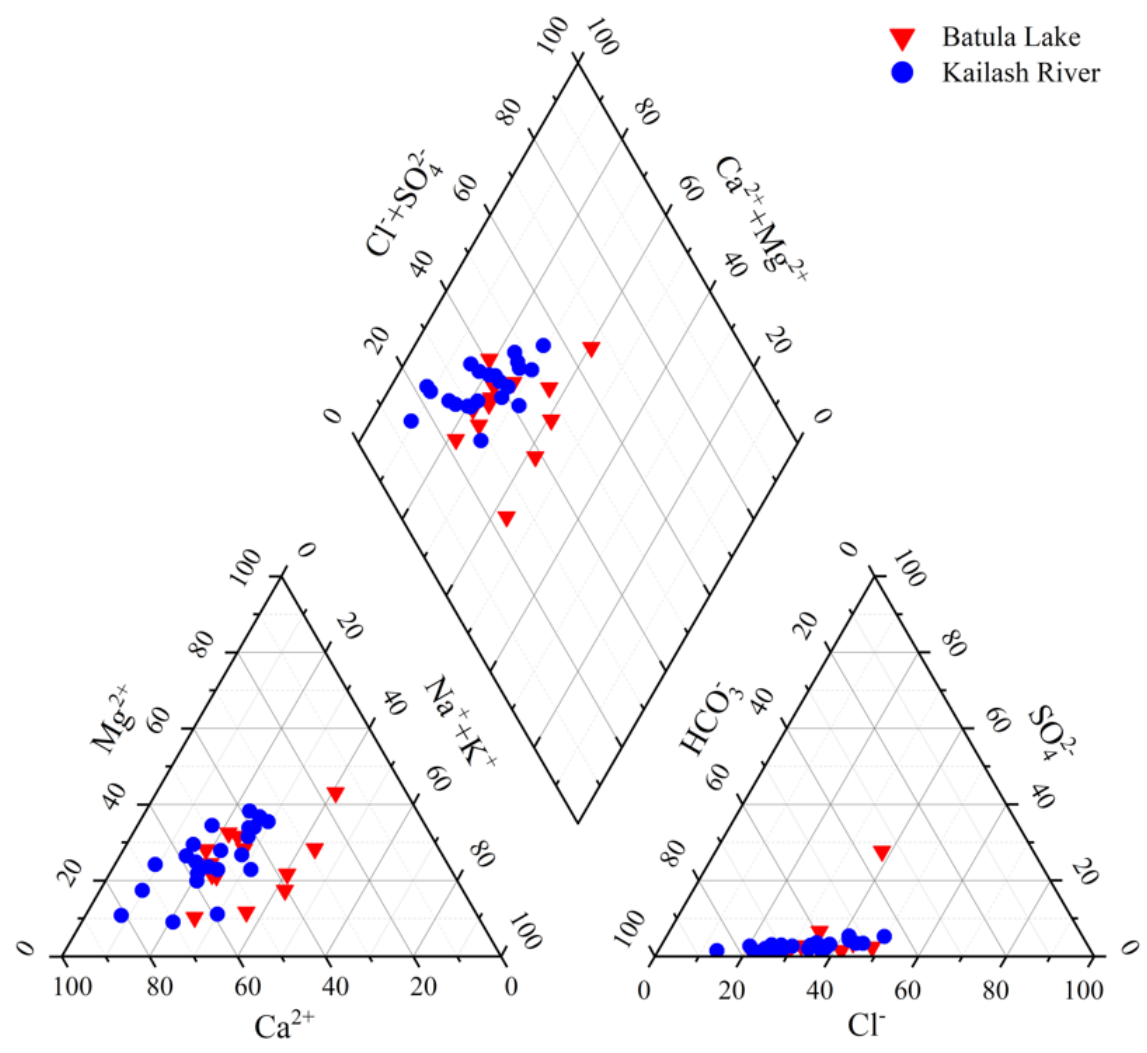

Figure 2: Piper diagram showing the hydrochemical facies of Batula Lake and Kailash River, Ramaroshan area, Sudurpaschim Province, Nepal

\section{Controlling mechanisms}

Gibbs Plot (Gibbs, 1970) shows the three mechanisms which control the water chemistry of the surface water: they are rock dominance, evaporation/crystallization, and precipitation. It is plotted between the TDS and $\mathrm{Na}^{+} / \mathrm{Na}^{+}+\mathrm{Ca}^{2+}$ and $\mathrm{Cl}^{-} / \mathrm{Cl}^{-}+\mathrm{HCO}_{3}^{-}$. Figure 3 showed that hydrochemistry of the Kailash River and Batula Lake was found to be precipitation dominant followed by rock weathering. The water samples from Batula Lake had a TDS value lower than $\mathrm{Na}^{+} / \mathrm{Na}^{+}+\mathrm{Ca}^{2+}$ and $\mathrm{Cl}^{-} / \mathrm{Cl}^{-}+\mathrm{HCO}_{3}^{-}$resulting in precipitation dominance. It indicates that atmospheric precipitation or runoff is the main factor controlling the composition of chemical components in the region. In the 
Gibbs diagram, 36.36\% samples of Kailash River lied in rock weathering dominance and the rest in precipitation dominance. The hydrochemistry of study lakes and rivers in Nepal like West Seti River Basin in Sudurpaschim Province (English et al., 2000), Begnas Lake (Khadka \& Ramanatha, 2012), Dudhkoshi River Basin (Paudyal et al., 2016), Rara Lake (Gurung et al., 2018), downstream of Gandaki River Basin (Pant et al., 2018) recorded rock weathering dominance which is a contrast to the present study.
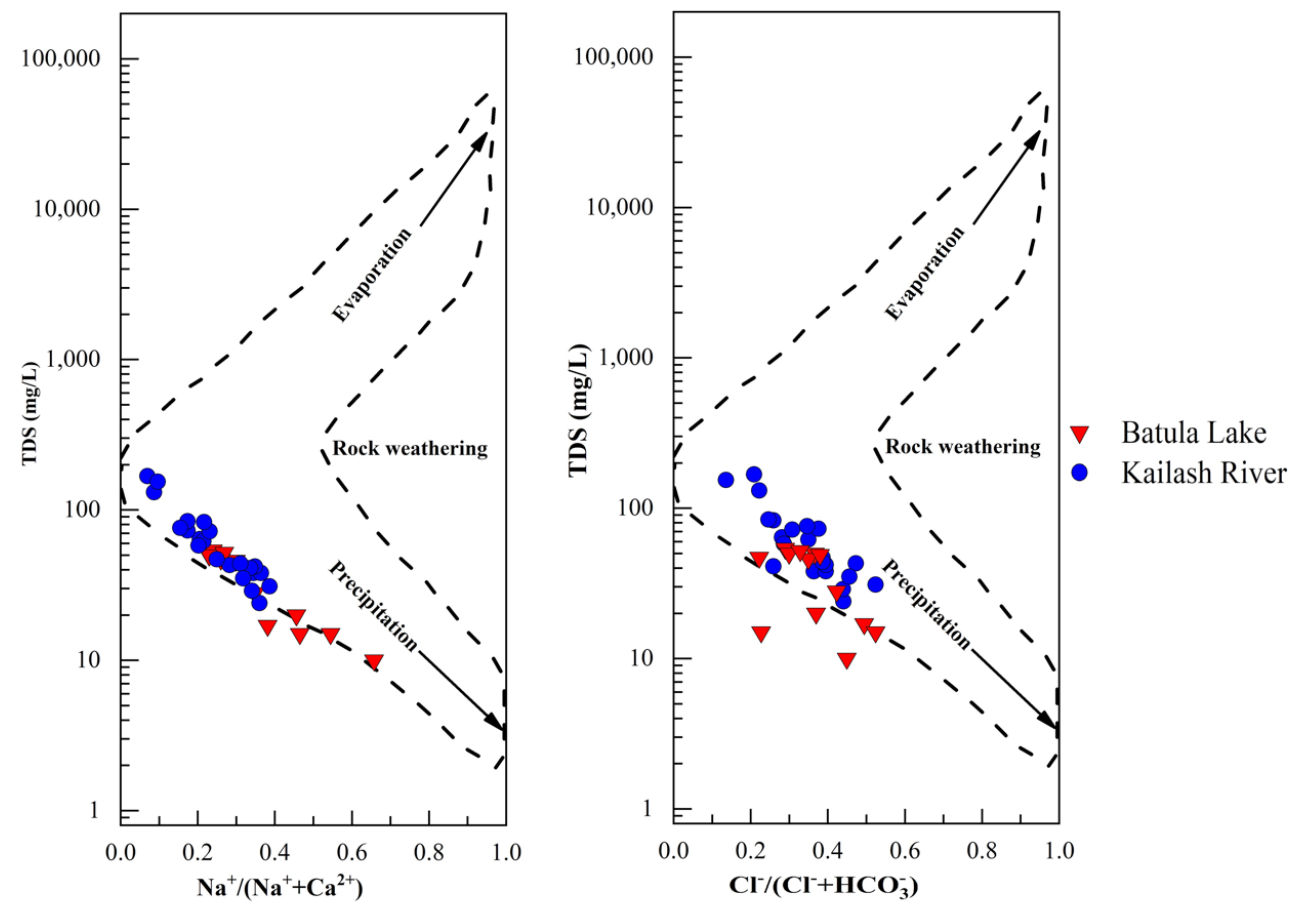

Figure 3: Gibbs plot showing major processes controlling surface water chemistry of the Batula Lake and Kailash River, Ramaroshan Area, Sudurpaschim Province, Nepal

(Concentration of $\mathrm{Na}^{+}, \mathrm{Ca}^{2+}, \mathrm{Cl}^{-}$and $\mathrm{HCO}_{3}^{-}$are in meq/L and TDS in $\mathrm{mg} / \mathrm{L}$ )

\section{Chemical weathering}

The major ions in the water bodies are contributed from the carbonate weathering, silicate weathering, and dissolution of evaporites. 
Table 2: Ionic ratios of hydrochemical variables of both Batula Lake and Kailash River, Ramaroshan area, Sudurpashchim Province, Nepal

\begin{tabular}{|c|c|c|c|c|c|c|c|c|}
\hline \multirow[t]{2}{*}{ Parameters } & \multicolumn{4}{|c|}{ Batula Lake } & \multicolumn{4}{|c|}{ Kailash River } \\
\hline & Average & Std & Max & Min & Average & std & Max & Min \\
\hline $\mathrm{Ca}^{2+} / \mathrm{Na}^{+}$ & 2.14 & 0.96 & 3.36 & 0.52 & 4.06 & 3.06 & 13.40 & 1.59 \\
\hline $\mathrm{Mg}^{2+} / \mathrm{Na}^{+}$ & 1.12 & 0.51 & 2.02 & 0.36 & 1.68 & 0.70 & 3.40 & 0.48 \\
\hline $\mathrm{HCO}_{3}^{-} / \mathrm{Na}^{+}$ & 2.69 & 1.04 & 4.11 & 1.07 & 3.58 & 2.26 & 9.26 & 1.30 \\
\hline $\mathrm{HCO}_{3}^{-} / \mathrm{Ca}^{2+}$ & 1.47 & 0.83 & 4.10 & 0.80 & 0.93 & 0.14 & 1.20 & 0.64 \\
\hline $\mathrm{HCO}_{3}^{-} /\left(\mathrm{Na}^{+}+\mathrm{K}^{+}\right)$ & 2.16 & 0.81 & 3.35 & 0.81 & 2.75 & 1.66 & 7.18 & 0.99 \\
\hline $\begin{array}{l}\left(\mathrm{Ca}^{2+}+\mathrm{Mg}^{2+}\right) / \\
\left(\mathrm{Na}^{+}+\mathrm{K}^{+}\right)\end{array}$ & 2.61 & 0.98 & 4.32 & 1.30 & 4.40 & 2.49 & 11.23 & 2.16 \\
\hline $\mathrm{Ca}^{2+} / \mathrm{SO}_{4}^{2+}$ & 41.24 & 42.09 & 124.91 & 1.06 & 29.30 & 16.08 & 76.83 & 10.50 \\
\hline $\mathrm{Na}^{+} / \mathrm{Cl}^{-}$ & 0.76 & 0.21 & 1.15 & 0.43 & 0.67 & 0.18 & 1.21 & 0.41 \\
\hline $\begin{array}{l}\mathrm{HCO}_{3}^{-/}\left(\mathrm{HCO}_{3}^{-+}\right. \\
\left.\mathrm{SO}_{4}^{2+}\right)\end{array}$ & 0.93 & 0.11 & 0.99 & 0.55 & 0.95 & 0.02 & 0.98 & 0.90 \\
\hline$\left(\mathrm{Ca}^{2+}+\mathrm{Mg}^{2+}\right) / \mathrm{Tz}^{+}$ & 0.71 & 0.09 & 0.81 & 0.57 & 0.79 & 0.07 & 0.92 & 0.68 \\
\hline$\left(\mathrm{Na}^{+}+\mathrm{K}^{+}\right) / \mathrm{Tz}^{+}$ & 0.29 & 0.09 & 0.43 & 0.19 & 0.21 & 0.07 & 0.32 & 0.08 \\
\hline
\end{tabular}

(All the concentrations are in $\mathrm{meq} / \mathrm{L}$ )

Mostly, $\mathrm{Ca}^{2+}$ and $\mathrm{Mg}^{2+}$ originate from the weathering of carbonates, silicates, and evaporite; $\mathrm{Na}^{+}$and $\mathrm{K}^{+}$from evaporites and weathering of silicates whereas $\mathrm{SO}_{4}{ }^{2-}$ and $\mathrm{Cl}^{-}$from evaporites. The mean ratio of $\mathrm{Na}^{+} / \mathrm{Cl}^{-}$was $<1$ for both Batula Lake and Kailash River which indicates the single source of sodium and chloride ions (Li et al., 2009). The result was in contrast with the study of Bagmati River (Pant et al., 2021) but similar to the study in Gandaki Basin River (Pant et al., 2018). The pollution in the Bagmati River might be the region for the multiple sources as Bagmati River flows through heavily populated city but the Kailash River flows through the rural area of Nepal.

Carbonate weathering is influenced by the protons. For the estimation of these sources and their origin whether from carbonation or oxidation, the $\mathrm{C}$-ratio of $\mathrm{HCO}_{3}^{-} / \mathrm{HCO}_{3}^{-}+$ $\mathrm{SO}_{4}^{2-}$ is studied (Brown et al., 1996). As per Pant et al., (2018), the C-ratio is $<0.50$ indicates the coupled chemical reactions of both carbonate dissolution and sulfide oxidation, whereas $\mathrm{C}$-ratio close to 1 indicates the carbonation reactions and dissociation of $\mathrm{CO}_{2}$ deriving protons from atmospheric inputs. The mean value C-ratio of Batula Lake and Kailash River was $>0.5$ i.e. 0.9 and 0.95 , respectively. This determines the carbonate reaction and $\mathrm{CO}_{2}$ deriving protons from the atmosphere. Again, the high ratio of $\mathrm{Ca}^{2+} / \mathrm{SO}_{4}{ }^{2-}$ i.e. $>20$ (Singh et al., 2014) for both lake and river confirmed carbonate as a major source of protons for rock weathering. 
The high mean ratio of $\mathrm{Ca}^{2+}+\mathrm{Mg}^{2+} / \mathrm{Tz}^{+}$is $>0.7$ and the low ratio $\mathrm{Na}^{+}+\mathrm{K}^{+} / \mathrm{Tz}^{+}$is $<0.3$ in both the lake and and the river. These suggested that carbonate weathering is higher than that of silicates and evaporates (Khadka \& Ramanathan, 2012) in the study area. The Na-normalized molar ratio plot of $\mathrm{Ca}^{2+} / \mathrm{Na}^{+}$versus $\mathrm{HCO}_{3}^{-} / \mathrm{Na}^{+}$showed spatial variability in hydrochemistry with end members of carbonate, silicate, and evaporites. In the present study, almost all the samples from Batula Lake and Kailash River were towards the carbonate end member indicating the dominance of carbonate weathering. Meanwhile, a few samples from Batula Lake were located near silicate end members, which indicates silicate weathering (Figure $4 a$ and $b$ ).
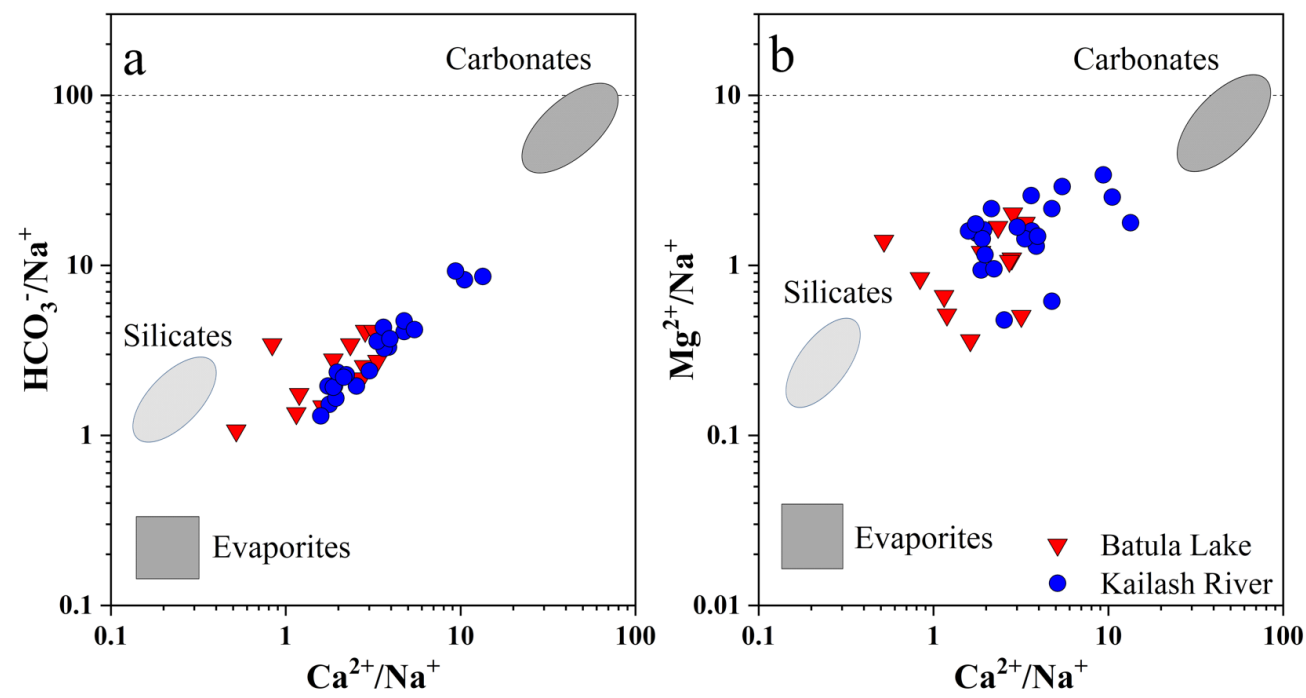

Figure 4: Mixing diagram of Na-normalized molar ratios of (a) $\mathrm{Ca}^{2+}$ versus $\mathrm{HCO}_{3}{ }^{-}$and (b) $\mathrm{Ca}^{2+}$ versus $\mathrm{Mg}^{2+}$, Ramaroshan area, Sudurpashchim Province, Nepal

\section{Multivariate analysis}

\section{Cluster analysis}

Hierarchical cluster analysis is the process to make clusters within a data set having similarities and build a hierarchy of clusters that are represented by the dendrogram (Figure 5). Hierarchical clustering with the Ward Method of Linkage was used to minimize the variance within the group. In hydrochemical studies, cluster analysis is used to group the similar sites having similar geochemical characteristics indicating the similar ongoing process affected by similar processes and sources (Saleh \& Shehata, 1999; Pant et al., 2018). In this study, the parameters like pH, EC, TDS, $\mathrm{HCO}_{3}$; $\mathrm{Ca}^{2+}$, $\mathrm{Mg}^{2+}, \mathrm{Na}^{+}, \mathrm{K}^{+}, \mathrm{Cl}^{-}, \mathrm{SO}_{4}^{2-}, \mathrm{NO}_{3}^{-}, \mathrm{PO}_{4}{ }^{3-}$ and $\mathrm{NH}_{4}^{+}$were used to cluster water sampling sites from the study area. 
Statistically, 3 clusters were obtained with a low distance criterion between 0 and 5 both from Batula Lake and Kailash River, respectively. Cluster 1 consists of $54.28 \%$ samples of both the lake and river. Cluster 2 consists of $37.14 \%$ of the total samples and Cluster 3 consists of only $8.57 \%$ samples. Interestingly, Cluster 3 contains only the samples from the river. These sites are characterized by the settlement area or small cluster settlements showing towards the anthropic activities. This determines that Cluster 3 has slightly polluted water sampling sites. These sampling sites are clustered together due to the high value of the EC, TDS, and major ions. These sites are the tributaries of that might be due to the use of this river as vehicles pathway. This cluster shows that the similarity in ongoing geological processes, similar climatic and anthropic factors.

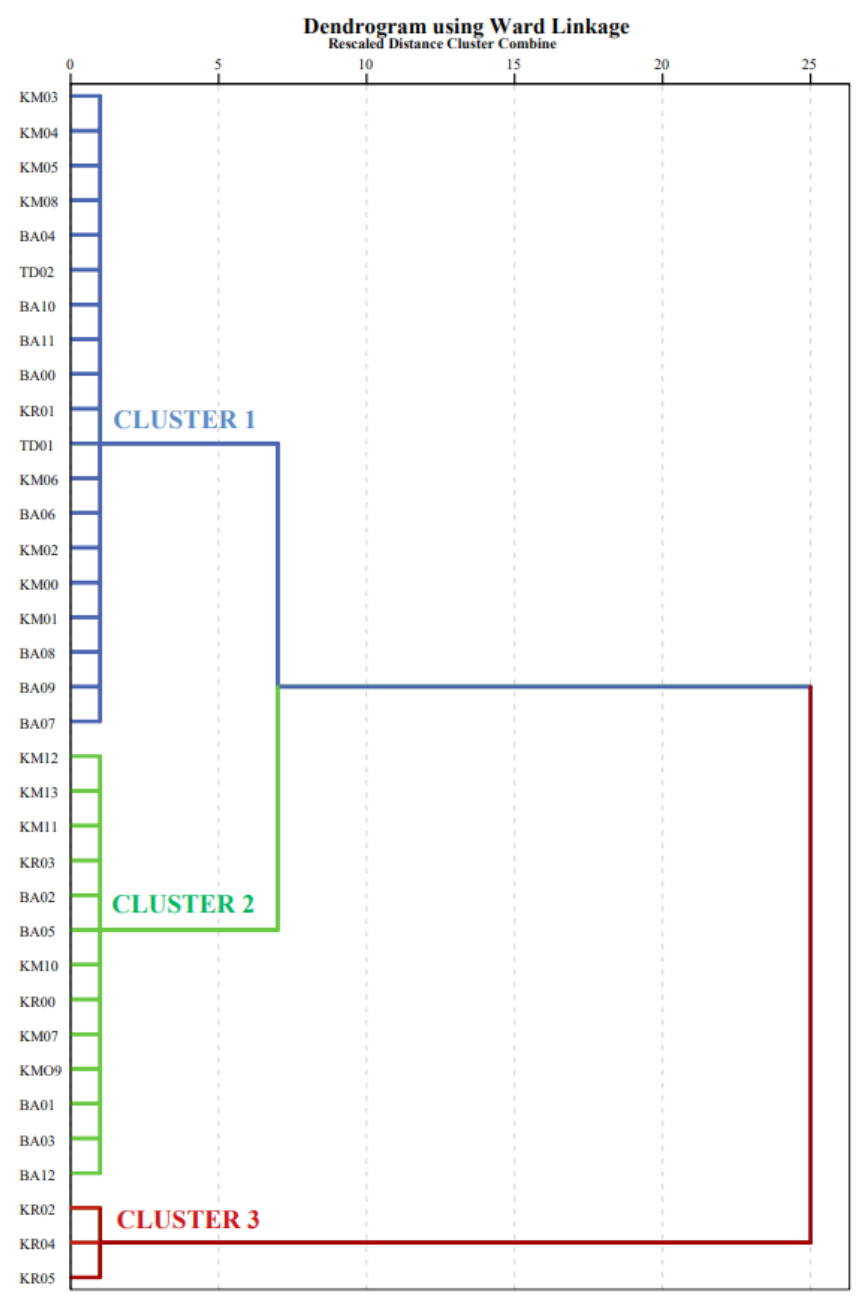

Figure 5: Cluster analysis of Batula Lake and Kailash River, Ramaroshan Area, Sudurpashchim Province, Nepal 


\section{Principal component analysis}

Principal component analysis (PCA) is commonly used for reducing the dimensionality of the data set with minimum loss of the original information. Principal components (PC) are extracted through the process of orthogonal transform of correlated variables to the set of linearly uncorrelated variables. The eigenvalues of the PCs are the degree of their associated variables whereas the correlation between PCs and original data is loadings (Verol et al., 1998).

For the identification of parameters influence in water, PCA was executed with the 11 parameters TDS, $\mathrm{HCO}_{3}^{-}, \mathrm{Ca}^{2+}, \mathrm{Mg}^{2+}, \mathrm{Na}^{+}, \mathrm{K}^{+}, \mathrm{Cl}^{-}, \mathrm{SO}_{4}^{2-}, \mathrm{NO}_{3}^{-}, \mathrm{PO}_{4}^{3-}$ and $\mathrm{NH}_{4}^{+}$of samples from the study area. In this study, the value of the Kaiser-Mayer-Olkin test was greater than 0.6 which shows the samples are adequate for the PCA test. The principal component (PCs) with the Eigenvalues greater than 1 was further analyzed (Figure 6) with the factor loading (Table 2). As per the PCA, 4 major principal components were observed for both Batula Lake and Kailash River. According to Liu et al., (2003), the factor loadings can be classified into the absolute loading values of $>0.75,0.75-0.50$, and $0.50-0.30$ as strong, moderate, and weak, respectively. In the present study, PC1 explained $39.055 \%$ total variance with the strong loading of $\mathrm{TDS}, \mathrm{HCO}_{3}^{-}$and $\mathrm{Ca}^{2+}$ in both the river and lake, and moderate loading of $\mathrm{Mg}^{2+}$, and $\mathrm{Cl}^{-}$. The strong loading plots of PC1 indicated that carbonate rock weathering impacted the hydrochemistry in the lake as well as the river. PC2 explained $18.32 \%$ of the total variance, having the strong loading on $\mathrm{NO}_{3}{ }^{-}$and moderate loading of $\mathrm{K}^{+}$and $\mathrm{PO}_{4}{ }^{3-}$. It indicated anthropic activities like forest and agricultural runoff and untreated sewage discharge or fecal contamination in lakes and rivers. Since, $\mathrm{NO}_{3}^{-}, \mathrm{K}^{+}$, and $\mathrm{PO}_{4}^{3-}$ lies in the same $\mathrm{PC}$ which indicates the similar source of these ions. Similarly, PC3 explained $13.02 \%$ of total variance having the strong loading of $\mathrm{Na}^{+}$and moderate negative loading on $\mathrm{NH}_{4}^{+}$, this indicates that the source of $\mathrm{Na}^{+}$and $\mathrm{NH}_{4}^{+}$is different in the region. Again, $\mathrm{PC} 4$ explained $9.05 \%$ of total variance having the strong loading on $\mathrm{SO}_{4}{ }^{2-}$ indicating the minimum anthropic signature in the area with the natural origin of $\mathrm{SO}_{4}^{2-}$. 
Table 3: Summary of principal component analysis showing a component matrix of Ramaroshan area, Sudurpashchim Province, Nepal

\begin{tabular}{lllll}
\hline Factor loading & \multicolumn{4}{l}{ Component matrix of Ramaroshan Area } \\
\cline { 2 - 5 } & \multicolumn{4}{l}{ Components } \\
\cline { 2 - 5 } & $\mathbf{0 . 9 5}$ & 0.17 & 0.10 & 4 \\
\hline $\mathrm{TDS}$ & $\mathbf{0 . 9 4}$ & 0.19 & -0.03 & -0.09 \\
$\mathrm{HCO}_{3}{ }^{-}$ & $\mathbf{0 . 6 0}$ & 0.07 & 0.26 & 0.02 \\
$\mathrm{Cl}^{-}$ & 0.35 & $\mathbf{0 . 7 8}$ & 0.12 & -0.35 \\
$\mathrm{NO}_{3}^{-}$ & 0.02 & -0.12 & -0.02 & $\mathbf{0 . 8 1}$ \\
$\mathrm{SO}_{4}{ }^{2-}$ & -0.16 & $\mathbf{0 . 6 1}$ & -0.38 & 0.48 \\
$\mathrm{PO}_{4}{ }^{2-}$ & $\mathbf{0 . 9 5}$ & 0.17 & 0.02 & 0.05 \\
$\mathrm{Ca}^{2+}$ & $\mathbf{0 . 6 3}$ & 0.14 & 0.25 & -0.12 \\
$\mathrm{Mg}^{2+}$ & 0.06 & 0.04 & $\mathbf{0 . 8 2}$ & -0.14 \\
$\mathrm{Na}^{+}$ & 0.32 & $\mathbf{0 . 6 3}$ & 0.19 & -0.19 \\
$\mathrm{~K}^{+}$ & -0.17 & -0.14 & $-\mathbf{0 . 6 0}$ & -0.43 \\
$\mathrm{NH}_{4}^{+}$ & 4.68 & 2.19 & 1.56 & 1.08 \\
\hline Eigen values & 39.05 & 18.32 & 13.02 & 9.05 \\
$\%$ of variance & 39.05 & 57.37 & 70.40 & 79.46 \\
Cumulative \% & & & & \\
\hline
\end{tabular}

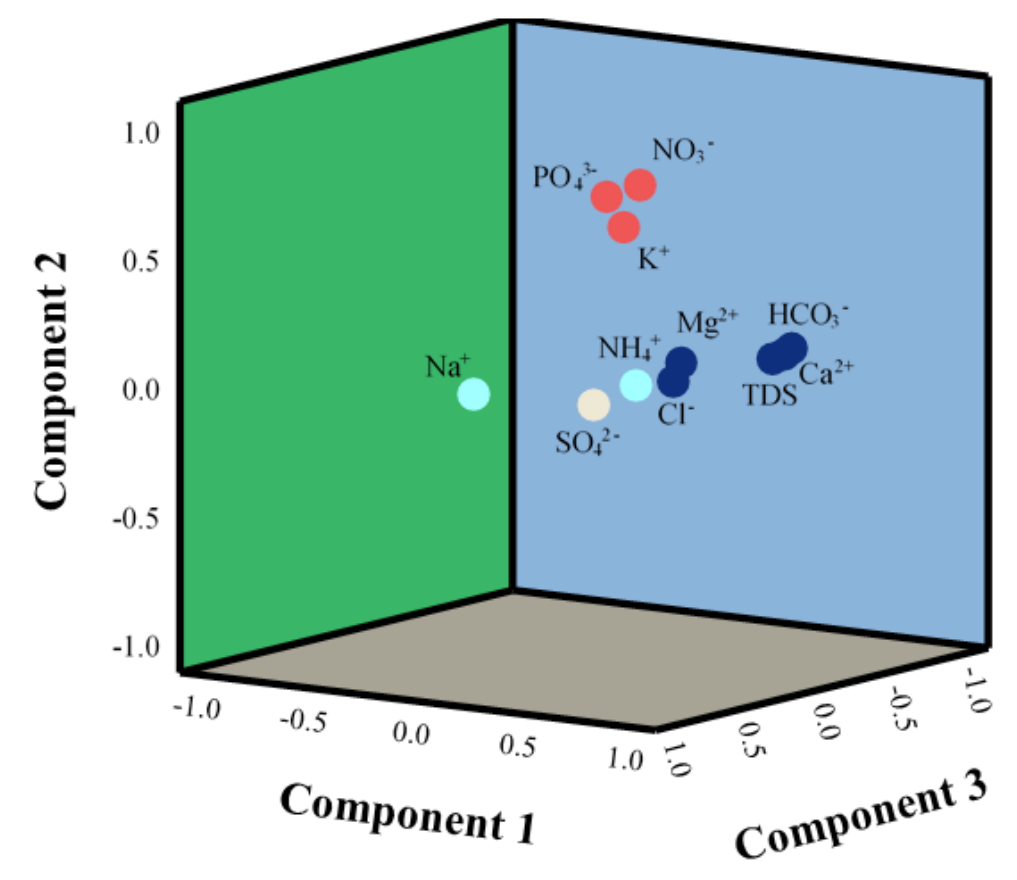

Figure 6: Principal component Batula Lake and Kailash River, Ramaroshan Area, Sudurpaschim Province, Nepal 


\section{Water quality for the irrigation purposes}

The river and lake water of the Ramaroshan area is widely used for drinking and irrigation purposes. Hence, the monitoring of water quality for irrigation is important to maintain soil health as well as crop production. In the long-term irrigated lands with poor water quality, salinization is a major problem especially in heavy and clayey soils (Singh et al., 2008). The water has high concentration dissolve ions alters the soil characteristics (Ravikumar et al., 2011) where $\mathrm{Na}^{+}$plays a vital role (Elango, 2005). The water suitability for irrigation based on $\mathrm{Na}^{+}$can be assessed by SAR, $\mathrm{Na} \%$, Wilcox Diagram, Kelly's Ratio, and permeability index (PI) whereas $\mathrm{Mg}^{2+}$ concentration is used to measure magnesium hazard.

SAR is used to calculate the sodium hazard, showing the degree of cation- exchange reaction in the soil and irrigation water. Generally, high sodium replaces the $\mathrm{Ca}^{2+}$ and $\mathrm{Mg}^{2+}$ of soil, increasing the soil's impermeability. In the present study, the mean values of SAR were $0.4 \pm 0.1$ and $0.33 \pm 0.1$ for Batula Lake and Kailash River, respectively. Since, SAR value was found to be $<10$ which shows the water quality is excellent based on classification (Singh et al., 2008). The previous study in Bagmati River, Gandaki River, Indrawati River, and Dudh Koshi River (Sharma et al., 2020), and Karmansha River (Acharya et al., 2020) showed that the water was suitable for irrigation based on SAR. According to Wilcox (1948), a Na \% value having less than $60 \%$ is suitable for irrigation purposes. The mean values of $\mathrm{Na} \%$ obtained were $30 \pm 8.7$ and $21.4 \pm 6.6$ of Batula Lake and Kailash River, respectively. Since all the sampling points had $\mathrm{Na} \%<$ $60 \%$ in the present study; thus, the water was suitable for irrigation in the Ramaroshan area.

Wilcox Diagram (1958) is used for assessing the suitability of irrigation water using the value of SAR and EC. In the Wilcox Diagram (Figure 7) C1, C2, C3, C4 types indicate salinity hazards, and S1, S2, S3, S4 types indicate sodium alkaline hazards. The majority of water samples from Batula Lake and Kailash River in the present study belonged to C1S1 i.e. low salinity with low sodium hazard whereas only two samples of Kailash River belonged to $\mathrm{C} 2 \mathrm{~S} 1$ i.e. medium salinity and low sodium hazard as shown in Figure 7. Thus, water was found to be suitable for the irrigation in Ramaroshan area. 


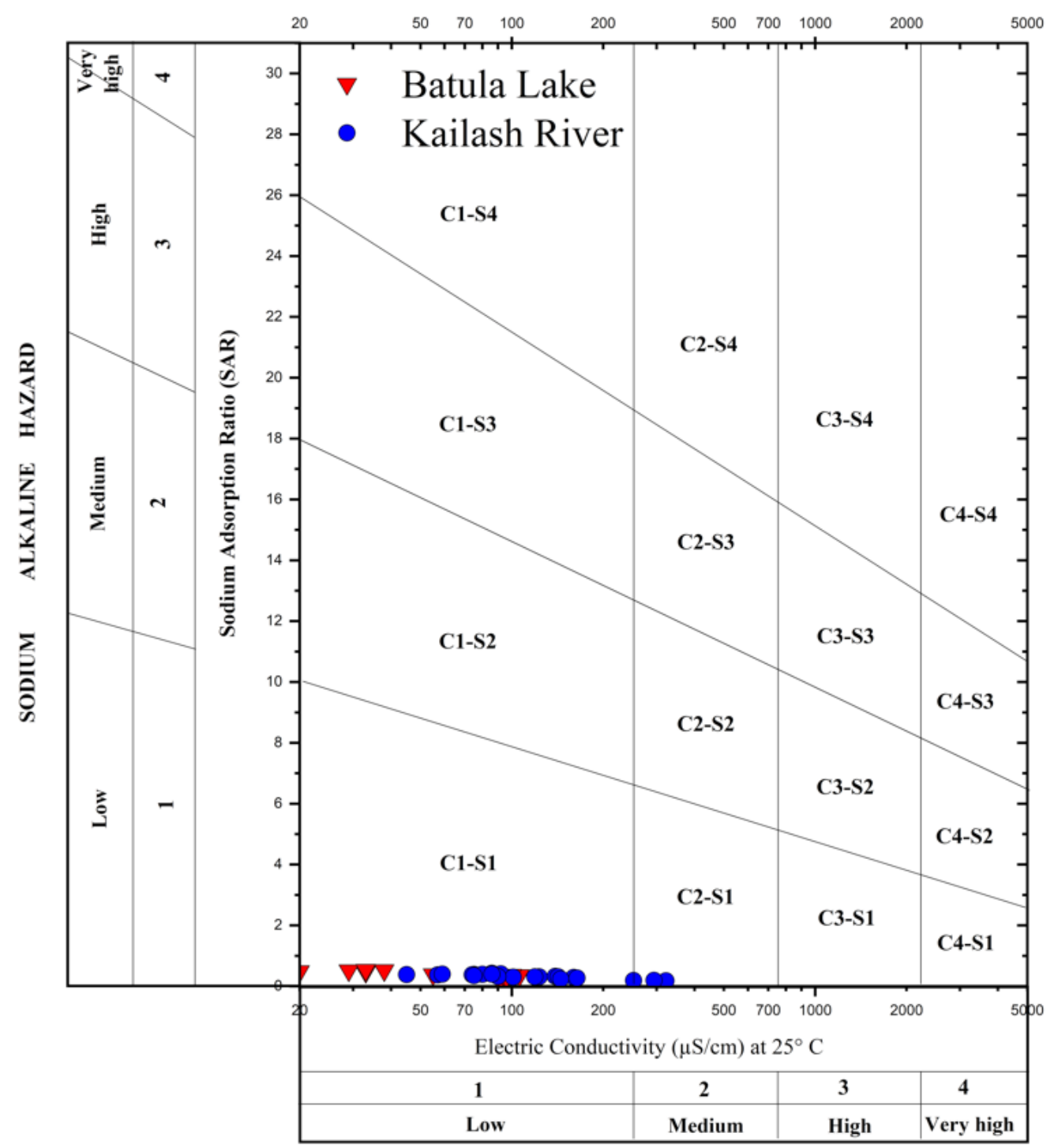

Figure 7: Wilcox showing the irrigation suitability of Batula Lake and Kailash River, Ramaroshan Area, Sudurpaschim Province, Nepal

Kelly's Ratio is the measurement of $\mathrm{Na}^{+}$against $\mathrm{Ca}^{2+}$ and $\mathrm{Mg}^{2+}$ (Kelly, 1940). Kelly's Ratio of more than one indicates water is unsuitable for irrigation. Kelly's ratio was lower than 1 in the present study indicated water suitable for irrigation. The mean values of Kelly's ratio were $0.36 \pm 0.2$ and $0.22 \pm 0.1$ for Batula Lake and Kailash River, respectively. The permeability of the soil is affected by the irrigation water quality 
and the soil type. The concentration of $\mathrm{Na}^{+}, \mathrm{Ca}^{2+}, \mathrm{Mg}^{2+}$, and $\mathrm{HCO}_{3}$ - contents in water mainly influence soil profile (Singh et al., 2015). On the basis of PI, water quality can be classified into Class I ( $>75 \%)$, Class II $(25 \%-75 \%)$, and Class III $(<25 \%)$ indicating excellent, good, and unsuitable for irrigation (Doneen, 1964). PI value for the waters samples varied from 74.89 to 178.83 and 42.58 to 99.63 of Batula Lake and Kailash River, respectively. So, the water samples lie in Class I and II category of (Doneen, 1964) which indicated water has excellent to good permeability and is suitable for irrigation.

Besides $\mathrm{Na}^{+}$, the monitoring of the $\mathrm{Mg}^{2+}$ ion in the water is required. Though $\mathrm{Mg}^{2+}$ and $\mathrm{Ca}^{2+}$ are in the equilibrium state in water, the high concentration of $\mathrm{Mg}^{2+}$ in irrigation increases the alkalinity and affects the crop yield. The water having $\mathrm{MH}>50$ is unsuitable for irrigation (Szabolcs \& Darab, 1964). The mean values of MH were $35.8 \pm 14.2$ and $33.05 \pm 11.6$ for Batula Lake and Kailash River, respectively. The majority of the samples didn't exceed the limits, so the water is suitable for irrigation.

\section{Conclusion}

The hydrochemistry of both the Batula and Kailash River of Ramaroshan Lake Complex, Sudurpashchim Province, Nepal were more or less similar in terms of their chemical concentrations. Among the major ions, calcium and bicarbonate were the most dominant cation and anion, which is consistent with $\mathrm{Ca}-\mathrm{HCO}_{3}$ dominate water type, indicating calcium carbonate type of lithology. The hydrochemistry of water was found to be controlled by rock weathering as well as precipitation. The analysis of irrigation parameters shows water in the Ramaroshan area is suitable for irrigation. This study builds the baseline dataset for assessing future anthropic influence on the water resource of the Ramaroshan area and subsequent development for future lake management strategies. However, the results of the present study are only based on a single season, so it is suggested for the monitoring of the water chemistry for different seasons for the in-depth insights. Additionally, along with the study of hydrochemistry at spatiotemporal level, the biological aspect is also recommended for the further study.

\section{Acknowledgments}

We would like to thank all the local residents of Ramaroshan Rural Municipality for their valuable cooperation and Mr. Ramesh Basnet for assisting with the laboratory analysis. Our special thanks to the Ministry of Industry, Tourism, Forests and Environment, Sudhurpaschim Province for the financial support. 


\section{References}

Acharya, A., Sharma, M. L., Bishwakarma, K., Dahal, P., Chaudhari, S. K., Adhikari, B., Neupane, S., Pokhrel, B. N., \& Pant, R. R. (2020). Chemical characteristics of the Karmanasha River Water and its appropriateness for irrigational usage. Journal of Nepal Chemical Society, 41(1), 94-102.

Adrian, R., O'Reilly, C. M., Zagarese, H., Baines, S. B., Hessen, D. O., Keller, W., Livingstone, D. M., Sommaruga, R., Straile, D., Van Donk, E, \& Winder, M. (2009). Lakes as sentinels of climate change. Limnology and Oceanography, 54(6part2), 2283-2297.Amangabara, G. T., \& Ejenma, E. (2012). Groundwater quality assessment of Yenagoa and environs Bayelsa State, Nigeria between 2010 and 2011. Resources and Environment, 2(2), 20-29.

APHA (2005) Standard methods for the examination of water and wastewater, 21st edn. American Public Health Association, Washington

Barnett, T. P., Adam, J. C., \& Lettenmaier, D. P. (2005). Potential impacts of a warming climate on water availability in snow-dominated regions. Nature, 438(7066), 303-309.

Battarbee, R. W. (2005). Mountain lakes, pristine or polluted?. Limnetica, 24(1-2), 001-8.

Begum, A., Ramaiah, M., Khan, I., \& Veena, K. (2009). Heavy metal pollution and chemical profile of Cauvery River water. E-journal of Chemistry, 6(1), 47-52.

Brown, G. H., Sharp, M., \& Tranter, M. (1996). Subglacial chemical erosion: seasonal variations in solute provenance, Haut Glacier d'Arolla, Valais, Switzerland. Annals of Glaciology, 22, 25-31.

CBS (2012). National population and housing census 2011. National Report. Government of Nepal National Planning Commission Secretariat Central Bureau of Statistics Kathmandu, Nepal.

Chalaune, T. B., Dangol, A., Sharma, J., \& Sharma, C. M. (2020). First results on Physico-chemical status and bathymetry of lakes in Ramaroshan Wetland, FarWest Nepal. Nepal Journal of Environmental Science, 8, 17-27.

Chandan, P., Chatterjee, A., \& Gautam, P. (2007). Management planning of Himalayan high altitude wetlands: A case study of Tsomoriri and Tsokar wetlands in Ladakh, India. In M. Sengupta \& R. Dalwani (Eds), Proceedings of Taal 2007: The 12th World lake conference. Jaipur, India, 28 October- 2 November 2007. New Delhi: Ministry of Environment and Forest, Government of India.

Das, B. K, \& Kaur, P, (2001). Major ion chemistry of Renuka Lake and weathering processes, Simaur District, Himachal Pradesh, India. Environmental Geology, 40(7), 908-917

DoF (2017), Wetlands of Western Nepal: A brief profile of Selected Lakes, Department of Forests, Babarmahal, Kathmandu, Nepal. 
Doneen, L. D. (1964). Notes on water quality in agriculture. Department of Water Science and Engineering, University of California, Davis.

English, N. B., Quade, J., DeCelles, P. G., \& Garzione, C. N. (2000). Geologic control of Sr and major element chemistry in Himalayan Rivers, Nepal. Geochimica et Cosmochimica Acta, 64(15), 2549-2566.

Gaillardet, J., Dupré, B., Louvat, P., \& Allegre, C. J. (1999). Global silicate weathering and $\mathrm{CO}_{2}$ consumption rates are deduced from the chemistry of large rivers. Chemical Geology, 159(1-4), 3-30.

Gautam, B., \& Bhattarai, B. (2008). Seasonal changes in water quality parameters and sediment

Ghimire, N. P., Adhikari, N., Pant, R. R., \& Thakuri, S. (2021). Characterizations of Water Quality in West-Seti and Tamor River Basins, Nepal. Scientific World, 14(14), 106-114.

Gibbs, R. J. (1970). Mechanisms controlling world water chemistry. Science 170, 1088-1090.

Grabherr, G., Gurung, A. B., Dedieu, J. P., Haeberli, W., Hohenwallner, D., Lotter, A.F., Nagy, L., Pauli, H., \& Psenner, R.(2005). Long-term environmental observations in mountain biosphere reserves: recommendations from the EU GLOCHAMORE project. Mountain Research and Development, 25(4), 376-383.

Gurung, S., Gurung, A., Sharma, C. M., Jüttner, I., Tripathee, L., Bajracharya, R. M., \& Kang, S. (2018). Hydrochemistry of Lake Rara: A high mountain lake in western Nepal. Lakes \& Reservoirs: Research \& Management, 23(2), 87-97.

Hagedorn, B., \& Whittier, R. B. (2015). Solute sources and water mixing in a flashy mountainous stream (Pahsimeroi River, US Rocky Mountains): Implications on chemical weathering rate and groundwater-surface water interaction. Chemical Geology, 391, 123-137.

Khadka, U. R., \& Ramanathan, A. L. (2013). Major ion composition and seasonal variation in the Lesser Himalayan Lake: the case of Begnas Lake of the Pokhara Valley, Nepal. Arabian Journal of Geosciences, 6(11), 4191-4206.

Li, S., Xu, Z., Wang, H., Wang, J., \& Zhang, Q. (2009). Geochemistry of the upper Han River basin, China: 3: Anthropic inputs and chemical weathering to the dissolved load. Chemical Geology, 264(1-4), 89-95.

Liu, C. W., Lin, K. H., \& Kuo, Y. M. (2003). Application of factor analysis in the assessment of groundwater quality in a blackfoot disease area in Taiwan. Science of the Total Environment, 313(1-3), 77-89.

Nazri, M. A. A., Tan, L. W., Kasmin, H., Syafalni, S., \& Abustan, I. (2016, July). Geophysical and hydrochemical characteristics of groundwater at Kerian irrigation scheme. In IOP Conference Series: Materials Science and Engineering (Vol. 136, No. 1, pp. 1-14).

Pal, K. B., Bishwakarma, K., Chalaune, T. B., Upadhaya, D., Joshi, T. R., Thapa, L. B., Sharma, M. L., Joshi, S., \& Pant, R. R. (2021). Hydrochemical assessment of Jhilmila Lake, Kanchanpur, Nepal. Scientific World, 14(14), 124-131. 
Pant, R. R. (2013). Water Quality Assessment of Nagdaha Lake, Lalitpur, Nepal. Journal of TUTA University Campus, 8, 52-56.

Pant, R. R., Bishwakarma, K., Qaiser, F. U. R., Pathak, L., Jayaswal, G., Sapkota, B., Pal, K. B., Thapa, L. B., Koirala, M., Rijal, K., \& Maskey, R. (2021). Imprints of COVID-19 lockdown on the surface water quality of Bagmati river basin, Nepal. Journal of environmental management, 289, 112522.

Pant, R. R., Pal, K. B., Adhikari, N. L., Adhikari, S., \& Mishra, A. D. (2019a). Water Quality Assessment of Begnas and Rupa Lakes, Lesser Himalaya Pokhara, Nepal. Journal of the Institute of Engineering, 15(2), 113-122.

Pant, R.R., Dhakal, T.M., Thapa, L.B., Baral, U., Dangol, A., Chalaune, T.B., Pal, K.B., (2019b). Water Quality Assessment of the Betkot Lake, Sudurpaschim Province, Nepal. North Am. Acad. Res. https://doi.org/https://doi.org/10.5281/zenodo.3566682

Pant, R. R., Zhang, F., Rehman, F. U., Wang, G., Ye, M., Zeng, C., \& Tang, H. (2018). Spatiotemporal variations of hydrogeochemistry and its controlling factors in the Gandaki River Basin, Central Himalaya Nepal. Science of the Total Environment, 622, 770-782.

Paudyal, R., Kang, S., Sharma, C. M., Tripathee, L., Huang, J., Rupakheti, D., \& Sillanpää, M. (2016). Major ions and trace elements of two selected rivers near Everest region, southern Himalayas, Nepal. Environmental Earth Sciences, 75(1), 46. Piper, A. M. (1944). A graphic procedure in the geochemical interpretation of water $\square$ analyses. Eos, Transactions American Geophysical Union, 25(6), 914-928.

Ravikumar, P., Somashekar, R. K., \& Angami, M. (2011). Hydrochemistry and evaluation of groundwater suitability for irrigation and drinking purposes in the Markandeya River basin, Belgaum District, Karnataka State, India. Environmental Monitoring \& Assessment, 173(1), 459-487.

Rengasamy, P., \& Marchuk, A. (2011). Cation ratio of soil structural stability (CROSS). Soil Research, 49(3), 280-285.

Richards, L. A. (1954). Diagnosis and improvement of saline and alkali soils (Vol. 78, No. 2, p. 154). Williams \& Wilkins .

Rupakheti, D., Tripathee, L., Kang, S., Sharma, C. M., Paudyal, R., \& Sillanpää, M. (2017). Assessment of water quality and health risks for toxic trace elements in urban Phewa and remote Gosainkunda lakes, Nepal. Human and Ecological Risk Assessment: An International Journal, 23(5), 959-973.

Schwartz, M. R., Bridger, J. C., \& Hyman, D. (2001). A validity assessment of aggregation methods for multiple key informant survey data. Community Development, 32(2), 226-237.

Sharma, C. M., Kang, S., Tripathee, L., Paudyal, R., \& Sillanpää, M. (2020). Major ions and irrigation water quality assessment of the Nepalese Himalayan Rivers. Environment, Development, and Sustainability, 1-13. 
Singh, A. K., Mondal, G. C., Kumar, S., Singh, T. B., Tewary, B. K., \& Sinha, A. (2008). Major ion chemistry, weathering processes, and water quality assessment in the upper catchment of Damodar River basin, India. Environmental Geology, 54(4), 745-758.

Singh, S. K., Srivastava, P. K., Singh, D., Han, D., Gautam, S. K., \& Pandey, A. C. (2015). Modeling groundwater quality over a humid subtropical region using numerical indices, earth observation datasets, and X-ray diffraction technique: a case study of Allahabad district, India. Environmental Geochemistry \& Health, 37(1), 157-180.

Singh, V. B., Ramanathan, A. L., Pottakkal, J. G., \& Kumar, M. (2014). Seasonal variation of the solute and suspended sediment load in Gangotri glacier meltwater, central Himalaya, India. Journal of Asian Earth Sciences, 79, 224-234.

Steingruber, S., \& Colombo, L. (2006). Impact of air pollution on Alpine lakes and rivers. Environmental studies no. UW-0619. Federal Office for the Environment. Berne, Switzerland.

Subramani, T., Elango, L., \& Damodarasamy, S. R. (2005). Groundwater quality and its suitability for drinking and agricultural use in Chithar River Basin, Tamil Nadu, India. Environmental Geology, 47(8), 1099-1110.

Szabolcs, I. (1964). The influence of irrigation water of high sodium carbonate content on soils. Agrokémia és Talajtan, 13, 237-246.

Tripathee, L., Kang, S., Huang, J., Sillanpää, M., Sharma, C. M., Lüthi, Z. L., ... \& Paudyal, R. (2014). Ionic composition of wet precipitation over the southern slope of central Himalayas, Nepal. Environmental Science \& Pollution Research, 21(4), 2677-2687.

Vega, M., Pardo, R., Barrado, E., \& Debán, L. (1998). Assessment of seasonal and polluting effects on the quality of river water by exploratory data analysis. Water Research, 32(12), 3581-3592.

Wilcox, L. V. (1948). The quality of water for irrigation use (No. 1488-2016-124600).

Wu, Z., Wang, X., Chen, Y., Cai, Y., \& Deng, J. (2018). Assessing river water quality using water quality index in Lake Taihu Basin, China. Science of the Total Environment, 612, 914-922.

Xiao, J., Jin, Z. D., Wang, J., \& Zhang, F. (2015). Hydrochemical characteristics, controlling factors, and solute sources of groundwater within the Tarim River Basin in the extreme arid region, NW Tibetan Plateau. Quaternary International, 380, 237-246.

Yang, L., Zhu, G., Shi, P., Li, J., Liu, Y., Tong, H., Hu, P., Liang, F., Pan, H., Guo, H. \& Zhang, Y. (2018). Spatiotemporal characteristics of hydrochemistry in Asian arid inland basin-a case study of Shiyang River Basin. Environmental Science and Pollution Research, 25(3), 2293-2302.

Zhu, G. F., Su, Y. H., \& Feng, Q. (2008). The hydrochemical characteristics and evolution of groundwater and surface water in the Heihe River Basin, northwest China. Hydrogeology Journal, 16(1), 167-182. 